\title{
Producers' approaches about good agricultural practices in Manisa and İzmir
}

\author{
Selcuk Karabat ${ }^{1}$ and Başak Aydın ${ }^{2}$ \\ ${ }^{1}$ Viticulture Research Institute, Manisa, Turkey \\ ${ }^{2}$ Atatürk Soil Water and Agricultural Meteorology Research Institute, Kırklareli, Turkey
}

\begin{abstract}
This study includes the agricultural enterprises which apply and do not apply good agricultural practices in Manisa and İzmir provinces. The basic purposes of this research are; to make a comparison between the enterprises apply and do not apply good agricultural practices, to determine the awareness of the producers to good agricultural practices, to specify the tendency of the farmers towards good agricultural practices and to present the factors affecting to good agriculture. In the scope of the study, 25 grape producers in Manisa and 20 mandarin producers in Izmir that apply good agricultural practices have been participated in a survey. Besides, the same survey was also conducted with the same number of producers which do not apply good agricultural practices. To analyze the data, simple calculations such as average, percentage, frequency and through the use of the crosstabs were used and the social-economic status of the producers and some technical and economical specifications of the enterprises were determined. The tendency of the producers towards performing good agricultural practices and the factors affecting to these tendencies have been observed. The tendency of the producers were determined by using Logit Regression Analysis.
\end{abstract}

\section{Introduction and objectives}

Today, society's greatest need is to provide safe food items. Rapid increase in the world population, environmental pollution due to developing technology, economic weakness and inadequate education deepen nutritional problems and make it difficult to provide safe food.

Emerging food technology and consumer consciousness are also increasing efforts to improve product quality. The production of foods with the basic requirements for the lives of the consumers in line with current technological requirements is an important service for providing healthy nutrition. Efforts to ensure food safety and quality assurance are also of great importance for consumer and community health.

Good Agricultural Practices (GAP) is one of the wellknown standards developed by the Food and Agriculture Organization (FAO) and presently GAP certification is a must for export in most of the developed countries. GAP aims at attaining social, economic and environmental sustainability by following certain criteria right from the planting of crop to the marketing [1]. Turkey with more than 4 million tons of grapes is the 6th largest producer of grapes in the world. Turkey also has the distinction of achieving the high production in mandarin in the world. More than 40 per cent of the total grape production is produced in Manisa-Turkey. Also 15 per cent of the total mandarin production is produced in Izmir-Turkey [2].

This study includes the agricultural enterprises which apply and do not apply good agricultural practices (GAP) in Manisa and İzmir provinces. The main objectives of the research; The economic comparison of farmers applying and not applying GAP in the area of research, determination of farmers' awareness of GAP, the determination of farmers' tendencies towards GAP and the factors affecting GAP.

\section{Data and methodology}

\subsection{Material}

The main material of the study was obtained from the surveys conducted with producers in İzmir and Manisa provinces. In addition, it has been used in previous domestic and foreign studies and statistics related to the research topic.

\subsection{Method}

According to the year 2013 data; 25 grape producers engaged in GAP in Manisa province; A total of 20 mandarin producers were surveyed in İzmir. A survey was conducted with the same number of non-GAP farmers in the study.

\subsubsection{Method used in analysis of data}

In the analysis of the data, using simple calculations such as average, percentage, and cross tables; some socio-economic characteristics of the surveyed producers and some technical and economic characteristics of the enterprises have been determined. Factors influencing the tendency of producers to make GAP were identified. 
Table 1. Some characteristics of GAP and Non-GAP producers.

\begin{tabular}{|l|l|l|}
\hline & $\begin{array}{l}\text { GAP } \\
\text { Farmers }\end{array}$ & $\begin{array}{l}\text { Non-GAP } \\
\text { Farmers }\end{array}$ \\
\hline Age of farmers (year) & 49,49 & 51,29 \\
\hline Education period (year) & 9,64 & 7,00 \\
\hline Number of family members & 3,91 & 4,56 \\
\hline Experience with agriculture (year) & 27,49 & 32,64 \\
\hline
\end{tabular}

GAP tendencies of producers were determined using Logit regression analysis.

Logit Regression is a nonlinear regression model specially designed for binary dependent variable. In the literature, Logit regression is also called "Logistic Regression" [3]. If the dependent variable in the model is expressed in two categories, then the model "Dual Logistic Regression Model" is called "Multiple Logistic Regression Model" if it is expressed in more than one category [4]. In the binary logistic regression model, the observed value of the dependent variable is 1 if the event occurs, 0 if the event does not occur, to express two possible states [5]. Logistic regression was developed by statistician David Cox in 1958. The binary logistic model is used to estimate the probability of a binary response based on one or more predictor (or independent) variables (features). It allows one to say that the presence of a risk factor increases the probability of a given outcome by a specific percentage. In this study, farmers' GAP status was taken as a dependent variable and 0 for those who did not 1 for GAP farmers.

\section{Findings and results}

The average age of the GAP producers was 49.49 and the average age of non-GAP producers was 51.29. GAP producers average year of education 9.64, NonGAP producers education year average is 7 years. The average number of family members of GAP producers was 3.91, and the average number of family members of non-GAP producers was 4.56. The average agricultural experience of GAP producers was 27.49 and the average agricultural experience of non-GAP producers was 32.64 years. GAP producers and non-GAP producers have also been statistically different in terms of education, number of family members and agricultural experience.

The average land size of GAP producers is 61.57 daa, and the average land size of non-GAP producers is 25.24 daa. The share of land belonging to GAP producers in total land was determined as $97.97 \%$, and the share of land belonging to non-GAP producers in total was determined as $95.76 \%$. As a result of the t-test to determine whether the difference in land size between GAP and NonGAP producers is statistically significant, $(P=0.004)$ between producers' land sizes at $1 \%$ significance level.

\section{Logistic regression analysis results}

Factors affecting GAP status of producers were analyzed using logistic regression model. In the binary logistic regression model used in the study, GAP (1) and non-GAP (0) were used as dependent variables.

The independent variables of the model are age, education, number of family members, agricultural
Table 2. Estimation results of the logistic regression model.

\begin{tabular}{|l|l|l|l|}
\hline Variables & Coefficient & Std Dv & P Value \\
\hline Constant & $-1,507$ & 3,052 &, 621 \\
\hline Age &, 042 &, 048 &, 378 \\
\hline Education &, 060 &, 111 &, 589 \\
\hline Num of family member &,- 436 &, 242 &, $072^{* *}$ \\
\hline Agr. Experience &,- 021 &, 041 &, 610 \\
\hline Non Ag. Job &, 246 &, 742 &, 741 \\
\hline Living place & 1,523 &, 638 &, $017^{* *}$ \\
\hline Mem. of an org. &, 038 &, 316 &, 904 \\
\hline Attitude towards innovations & $-1,206$ &, 570 &, $034^{*}$ \\
\hline Number of tractor &, 273 &, 814 &, 738 \\
\hline Land size &, 019 &, 033 &, 568 \\
\hline Total revenue &, 000 &, 000 &, 727 \\
\hline Number of cattle &,- 053 &, 039 &, 173 \\
\hline Nagelkerke R Square $=0,52$ & \\
\hline-2 Log likelihood =79,74 \\
\hline$X^{2}=9,374 \quad p=0,312($ Hosmer and Lemeshow test $)$ \\
\hline$X^{2}=42,632 \quad P=0,000($ Omnibus test $)$ \\
\hline \multicolumn{4}{|l}{} \\
\hline
\end{tabular}

experience, non-agricultural income, living place, attitude towards innovations, and number of tractor, land size, total revenue, and total cattle.

The GAP approaches of producers were estimated using the logistic regression model and the results obtained are given in Table 2. The coefficients of the variables used in the model to determine the GAP approaches of the producers were quite different and statistically significant $(\mathrm{p}=0,000)$. The independent variables account for $52 \%$ of the dependent variable. As a result of the Hosmer Lemeshow test, the chi square value was calculated as 9,374. $\mathrm{p}$ value was obtained as $\mathrm{p}=0,312>0,05$, indicating that the model is appropriate.

The age, education, non-agricultural income, membership of an organization, number of tractor, land size and total revenue are variables included in the model affects the GAP in the positive direction, the agricultural experience and the number of cattle in the negative direction. These variables are statistically insignificant $(\mathrm{p}>0,10)$.

The number of family members of the producers affected GAP status $(\mathrm{p}=0.072)$ at the $10 \%$ significance level on the negative side.

The producers' living place affects the GAP status positively at the $5 \%$ significance level $(\mathrm{p}=0.017)$. The GAP tendencies are increasing as the place where the producers are residing moves from the villages to the small cities. This may be a sign that residence in the county or city provides easy access to the most effective pesticides retailers and governmental agricultural organization units among the consulting resources. As the place of residence of a non-GAP producer moves towards the city, the probability of participating the GAP increases 4.587 times.

Producers' approaches to innovations have a positive impact on good agricultural practice at a 5\% significance level $(\mathrm{p}=0.034)$. GAP approaches are increasing as producers increase their positive attitudes towards agricultural investment and technology. This situation is an expected result. As the positive attitude for innovations of a non-GAP farmer increases, the GAP participating probability increases by 0.299 . 


\section{References}

[1] FAO report, Development of a Framework for Good Agricultural Practices, Rome (2003)

[2] TUİK, (Turkish Statistical Institute) Agricultural Production Statistics. (www. tuik.gov.tr) (2015)

[3] Stock, J. H., Watson, M W. Introduction to Econometrics, Pearson Addison Wesley, Boston (2007)
[4] Leech, N. L., Barrett, K. C., Morgan, G. A. SPSS For Intermediate Statistics: Use and Interpretation, Lawrance Erlbaum Associates Publishers, Manwah New Jersey (2004)

[5] Walker, S. H., Duncan, D.B. "Estimation of the Probability of an Event as a Function of Several Independent Variables", Biometrika 54, 167-179 (1967) 